\title{
Biophilic Design and Climate Change: Performance Parameters for Health
}

\author{
Julia Africa ${ }^{1 *}$, Judith Heerwagen ${ }^{2}$, Vivian Loftness ${ }^{3}$ and Catherine Ryan Balagtas ${ }^{4}$ \\ 1 Independent Researcher, Boston, MA, United States, ${ }^{2}$ U.S. General Services Administration, Office of Federal High \\ Performance Buildings, Washington, DC, United States, ${ }^{3}$ School of Architecture, Carnegie Mellon University, Pittsburgh, PA, \\ United States, ${ }^{4}$ Terrapin Bright Green LLC, New York, NY, United States
}

\section{OPEN ACCESS}

Edited by:

Patricia Romero-Lankao,

National Renewable Energy

Laboratory (DOE), United States

Reviewed by:

Mohammadtaghi Moravej,

Extreme Events Institute, Florida International University, United States

Forrest Meggers,

Princeton University, United States

*Correspondence:

Julia Africa

africa@post.harvard.edu

Specialty section:

This article was submitted to

Urban Science,

a section of the journal

Frontiers in Built Environment

Received: 01 November 2018 Accepted: 20 February 2019

Published: 19 March 2019

Citation:

Africa J, Heerwagen J, Loftness V and

Ryan Balagtas C (2019) Biophilic

Design and Climate Change:

Performance Parameters for Health.

Front. Built Environ. 5:28.

doi: 10.3389/fbuil.2019.00028
Biophilic design is one of a number of trending design practices that rely on nature-based systems, engineering principles and design cues to improve environmental quality, health, and efficiency. Biophilic design integrates but does not appropriate the contributions of other nature-based design techniques precisely because it can act as a platform or "interstitial tissue," providing a connective language/practice/ethos that can unite disparate practices in the built environment more broadly. This paper provides an illustrative compilation of how biophilic design practices can directly support resilience in human health and the built environment on behalf of the International Living Future Institute's Biophilic Design Advisory Board. We strongly advocate the use of metrics related to climate change mitigation as a dimension of performance analysis for biophilic design practices as a demonstration of professional mindfulness and responsibility.

Keywords: resilience, health, adaptation, building performance, biophilic design

As a global biophilic design community, loosely drawn but defined by the use of a common palette to support health and happiness in the built environment, we want to encourage awareness of and responsiveness to the larger context of climate change in our projects. This essay articulates the relationship between biophilic design practices and climate-change related shifts in environmental health, proposing that practitioners foreground projected benefits to individual and communal health and resilience discussing their work. This represents a subtle but important shift in the perceived value of biophilic design interventions and is submitted on behalf of the International Living Future Institute's Biophilic Design Advisory Board ${ }^{1}$ to support contemporary ethical conduct in our industry.

Biophilic design is a holistic practice utilizing nature-based systems, engineering principles, and design cues to support improved health, well-being and performance as measured through personal biometrics, self-rated mood, and work quality (Ryan and Browning, 2018). As compared to landscape urbanism, ecological infrastructure, or vestiges of the "green city movement," the best applications of biophilic design may be distinguished from other projects by their ability to synergistically integrate the building, site, and occupants through the creation of comprehensive "habitat." Habitat, in this context, encompasses the materials, structure and program of the building; management of site metabolism, including energy needs and waste flows; concordance with the surrounding environment, both within the building and beyond the building façade;

\footnotetext{
${ }^{1}$ ILFI Biophilic Design Advisory Board members are as follows: Erin Jende, Judith Heerwagen, Julia Africa, David Gerson, Richard Piacintini, William Browning, Vivian Loftness, Nicole Isle, Catherine Ryan Balagtas, Mary Davidge, Sonja Bochart, Amanda Sturgeon, Malaysia Marshall and Tim McGee.
} 
support for on-site biodiversity, from micro to macro fauna (as appropriate); and perhaps most of all, a recognition that these features communicate habitability and community to human occupants through eons of evolutionary priming, and that this appeal is both desirable, comfortable, and health promoting.

Biophilic design is justifiably critiqued for its inequity: the health, happiness and productivity of humans is privileged over that of other species, and (de facto) the approach is most accessible among clients of means. We are hopeful that this will not always be the case, and growing popular interest suggests that a more generous market base will improve the distribution of biophilic design practices in the future. Biophilic design integrates but does not appropriate the contributions of other nature-based design techniques precisely because it can act as a platform or "interstitial tissue," providing a connective language, practice or ethos that unites disparate disciplines in the built environment more broadly. We submit that biophilic design is both a specific approach that can be realized through "patterns" (Kellert et al., 2008; Kellert, 2015; Ryan and Browning, 2018) or validated through "outcomes" (Browning et al., 2012; Beatley and Newman, 2013; Ryan et al., 2014) as well as a platform for integrating nature-based design practices to address the experience of climate change in the built environment. Furthermore, we strongly advocate the use of metrics related to climate change mitigation as a dimension of performance analysis for biophilic design practices as a demonstration of professional mindfulness and responsibility.

As the saying goes, the future is already here, it's just not very evenly distributed. Climate change is projected to be the most serious threat to global economic, social and environmental stability in recorded history, with mild to severe disruptions globally affecting populations with unequal leverage for adaptation, mitigation and resilience (Bernstein, 2014; Special Report on Global Warming of $1.5^{\circ} \mathrm{C}$, 2018). Many prevalent human diseases are linked to climate fluctuations, from cardiovascular mortality and respiratory illnesses due to heat waves, to altered transmission of infectious diseases and malnutrition from crop failures or diminished nutrient availability. These problems are amplified by sociopolitical displacement (including resource shortage-related war or climate change refugees) and profound economic disruptions. As a result, many populations face significantly increased health challenges in the coming decades; those considered particularly at risk include children, pregnant women, immuno-compromised or obese adults, and populations existing in informal or nonformal communities (slums, refugee camps, stateless individuals) that may be underserved by traditional social, civic, or healthcare services.

The built environment cannot be held accountable for all of these problems but, as both a primary engine for resource extraction and use as well as the context in which mitigation and stewardship strategies are developed, we bear a responsibility to be forward-thinking, whether through specific building technologies, site programming, or regenerative design. The dominant socio-economic model for most nation states in the world today relies on intensive and ultimately unsustainable natural resource extraction and utilization. By way of example,
Earth Overshoot Day (EOD) refers to the calendar date on which humanity's resource consumption for the year exceeds Earth's capacity to regenerate those resources that year and this date, though illustrative, comes earlier each year. Biophilic design can play a major role in helping reconnect occupants to the biome and the building to the intrinsic "carrying capacity" of the site. It is this holistic vision of restoration and reconnection that grounds specific responses to climate change through biophilic design practice. Ultimately, our disconnection from the natural environment that has supported human civilization imperils every living being on the planet. In the Anthropocene, a geological era wherein global environmental conditions are manipulated by human activities, we have unfortunately appointed ourselves as masters of planetary fate.

Changes in the built environment and urban programming can attenuate our exposure to climate fluctuations. Projected incidence of severe storms and extreme precipitation, while threatening, do not directly demand individual physiological adaptation in the way that extreme heat does. Although there is considerable variation in heat tolerance between regionally dispersed human populations (Li et al., 2015), there are physiological limits to adaptation. Thermoregulation and acclimatization determine human heat tolerance and vulnerability to heat stress (Hanna and Tait, 2015); both processes are modulated by individual factors including age, health, aerobic fitness, and genetics (Kovats and Hajat, 2008). We are comfortable within a relatively narrow range of temperatures and atmospheric gas levels, with slightly elevated tolerance to extremes requiring genetic predisposition or environmental conditioning. Species usually adapt to different climatic conditions at a rate of only by about $1 \mathrm{C} / 1.8 \mathrm{~F}$ per million years; if global temperatures rise by 4 degrees in the next 100 years as predicted by the Intergovernmental Panel on Climate Change (IPCC), there simply won't be time for the morphological or metabolic changes needed for most species to successfully adapt (Quintero and Weins, 2013; Hanna and Tait, 2015). In the presence of extreme heat, for instance, research indicates increased likelihood of suppressed appetite, diminished cognitive performance, and increased irritability; as temperatures increase, strain on the circulatory system endangers lung, heart, and brain function. "Wet bulb" temperatures incorporate humidity; as levels approach the core body temperature of 98.6 degrees, thermodynamic heat transfer cannot shed baseline metabolic heat generation through sweat. Temperatures above $58.3 \mathrm{C} / 137 \mathrm{~F}$ make any strenuous outdoor activity critically dangerous (potentially fatal) and above $74 \mathrm{C} / 165 \mathrm{~F}$ deadly for even healthy adults resting in the shade. Although these extremes are still relatively rare, prolonged heat and humidity pose significant threats to public health globally. In 2018, 354 major cities experienced average summer temperatures in excess of $35 \mathrm{C} / 95 \mathrm{~F}$; by 2050 , climate change will push this to 970 cities representing nearly 1.6 billion people, according to the recent "Future We Don't Want" study by the C40 alliance of the world's biggest metropolises (C40 Cities). Furthermore, "strong agreement exists across all models, that all areas on the globe will endure future temperature extremes far more severe than the recent extreme heat events which have already killed thousands, 
devastated crops, interrupted infrastructure functioning, caused major urban disruption, and delivered massive economic and development burdens" (Hanna and Tait, 2015).

We have the ability to anticipate and, to some degree, attenuate some of these disruptions to population health through our urban planning strategies and built environment. More than $70 \%$ global $\mathrm{CO}_{2}$ emissions (through the resource extraction, material fabrication, transport, and construction activities) is attributed to the generation and maintenance of cities; a new analysis mapping residential carbon dioxide emissions in 13,000 cities found that just 100 cities account for $20 \%$ of humanity's overall carbon footprint (National Academies of Sciences, Engineering, and Medicine, 2017; Miller, 2018). Excessive energy use, whether through flawed design and management or overdesign of building systems, coupled with non-renewable energy supply choices compounds the effect of existing building stock. Destruction of existing carbon sequestration ecologies and inadequate restoration of fallow land limits our ability to recapture ambient atmospheric carbon. This neglects the significant damages wrought the complex interactions of other pollutants and environmental factors i.e., formaldehyde, a common contaminant emitted by building materials, breaks down in sunlight to form ground level ozone, a significant respiratory hazard with the potential to damage atmospheric conditions. Conversely, the use of nature and natural design cues within the built environment reflects innate preferences for materials, forms and sensory cues that support the experience of health and well-being through several pathways: site-sensitive design aligns the building with its ecological (biome) context, net-zero or net-positive (waste filtration, energy production, heat island mitigation) performance, habitat preservation/restoration to support biodiversity while limiting vector-borne disease agents, water table restoration through infiltration, and flexible programming enabled by green space/nature for recreation, refuge and restoration. In addition, research suggests that green space is protective for mental health and improves all-cause health outcomes, potentially counteracting the influence of socioeconomic disparities on both disease incidence and progression (Frumkin et al., 2017).

In ways not yet entirely understood, biophilic design features can extend the effect of exposures (or memories of exposures) found outside of the building by acting on established neurobiological pathways (Africa, 2015). For example, someone might experience a reduction in mental fatigue during a walk in a woodland abutting their office, and on their return they might reconnect with those feelings of spaciousness and clarity through an office window with a view of the woodland or design elements (pictures, materials, sounds) drawn from the surrounding landscape. Although difficult to quantify, some measure of psychological security can be drawn from the timelessness and resilience of nature in our immediate surroundings; conversely, we may associate peril with its absence or dramatic disturbance. Preparation for severe natural disasters such as strong storms, floods, and droughts cannot be managed individually and rely on a trinity formed by human networks, ecological services, and environmentally responsive planning to restore of health and safety. To encourage more widespread adoption of biophilic design strategies, traditional value propositions (beauty; stress relief; intellectual, and commercial productivity) and the "checklist" mentality must expand to privilege resilience (distributed infrastructure, flexible programing, renewable materials, climate stabilization) and regenerative design (i.e., buildings which improve site ecology and occupant health). Ultimately survival-or perhaps even the prospect of flourishing in radically changed and changing conditions-is the highest accolade we can and should aspire to. To the extent that occupants directly relate their health and well-being to facets of their immediate built environment, they may by virtue of biophilia become impassioned advocates for nature, or design, or well-ness practices-or all of the above. Buildings are critical catalysts for advocacy.

The following points summarize key practice areas where the application of Biophilic Design (BD) solutions can sharpen responses to climate change in the built environment and increase resilience for both structures and occupants alike.

\section{BD SUPPORTS LOW ENERGY BUILDINGS TO DIMINISH DRIVERS OF CLIMATE CHANGE}

Deep conservation and passive solar can ensure comfort to outdoor temperatures as low as $45 \mathrm{~F}$. External living walls can cool façades and indoor spaces through shading and evapotranspiration; the presence of greenery can also lessen the perceived temperature (Sheweka and Mohamed, 2012; Hoelscher et al., 2016). Given appropriate façade and floor plan design, daylight can meet daytime lighting needs for visual comfort while reducing building electrical and cooling costs. Operable windows providing natural ventilation can enhance comfort while reducing the need for mechanical filtration/circulation. Natural ventilation may not be suitable in certain seasons, at certain sites, or in the context of certain programming needs that call for sterile or "clean" fields (i.e., hospitals, laboratories, or manufacturing centers that are sensitive to climate and humidity). The effect of natural ventilation on the indoor microbiome and occupant health is a site of active research with no definitive guidelines yet (National Academies of Sciences, Engineering, and Medicine, 2017).

\section{BD CONTRIBUTES TO HUMAN COMFORT IN THE FACE OF CLIMATE CHANGE}

Tactical biophilic interventions can "tune" urban microclimates through the provision of shade and windbreaks (Watts et al., 2015), the creation of hydrological cycles, and support for managed infiltration of stormwater to provide both the sensorial experience and perception of stability and refuge (Grahn and Stigsdotter, 2010). Natural settings like landscaped campuses, atria, rooftops, and shoreline esplanades that embody or recall an oasis of ecological normalcy (e.g., the experience of seasons, historical leisure activities or the passage of time) foster psychological stability and anchor resilience. Contact with salutogenic natural elements through views, materials, sounds, and architecture during discrete periods when recreation and relaxation outside are less safe can buffer individual 
and community stressors. Circadian-effective lighting strategies support overall health and, specifically, help regulate sleepwake cycles that are projected to be further disrupted by elevated nighttime temperatures (Laurent et al., 2018). With appropriate management (of invasive species, pollen, mold, mildew, microbes, etc.), most natural materials (wood, stone, water, etc.) are healthier for occupants given that they are unlikely to contain "red-listed" materials and may also have lower embodied carbon footprints due to relatively minimal processing.

\section{BD CONTRIBUTES TO MENTAL, EMOTIONAL AND SOCIAL HEALTH IN THE FACE OF CLIMATE CHANGE}

Familiarity with nature and natural design cues reinforce environmental education, stewardship and advocacy. Communal spaces like green roofs, atria, and gardens are pro-social and encourage social cohesion (Williams, 2017). Relationships developed in these spaces knits a kind of "social infrastructure" that is the warp and weft of resilience and adaptation (Klinenberg, 2018) Exposure to natural environments benefits emotional, physical, cognitive, and social development in children and adults (Africa et al., 2013; Dadvand et al., 2015; Frumkin et al., 2017) at a time when communities need enhanced support (Barton and Pretty, 2013; Brown et al., 2013) to manage environmental stressors related to climate change. Finally, interventions that support biodiversity (Fuller et al., 2007) (from microbes and pollinators to mega-fauna) contribute directly and indirectly to human health. The potential for human-wildlife conflict and increased vector-borne disease bearing insect habitat needs to be managed. In any building that coordinates natural materials or inputs with more conventional building management systems, living materials or installations (living walls, etc.) may create increased demands related to air filtration, lighting, pest control, and irrigation. Given the potential impact on the energy balance of the site, biophilic interventions may require deliberate and careful continuous tuning of the cost and value.

\section{REFERENCES}

Africa, J. (2015). An Underlying Issue: Health Benefits of Nature. DIRT Blog (American Association of Landscape Architects). Available online at: https://dirt.asla.org/?s=underlying+issue+health+benefits+nature (Accessed October 26,2018)

Africa, J., Logan, A., Mitchell, K., Korpela, K., and Allen, D. (2013). The Natural Environments Initiative: Illustrative Review and Workshop Statement. Available online at: https://www.nps.gov/public_health/hp/hphp/press/Paper_ NEI_Final.pdf (Accessed December 18, 2018).

Barton, J., and Pretty, J. (2013). What is the best dose of nature and green exercise for improving mental health. Environ. Sci. Technol. 44, 3947-3955. doi: $10.1021 /$ es $903183 \mathrm{r}$

Beatley, T., and Newman, P. (2013). Biophilic cities are sustainable, resilient cities. Sustainability 5, 3328-3345. doi: 10.3390/su5083328

Bernstein, A. S. (2014). Biological diversity and public health. Annu. Rev. Public Health 35, 11.1-11.15. doi: 10.1146/annurev-publhealth-032013-182348

Brown, D. K., Barton, J. L., and Gladwell, V. F. (2013). Viewing nature scenes positively affects recovery of autonomic function following acute-mental stress. Environ. Sci. Technol. 47, 5562-5569. doi: 10.1021/es305019p

\section{BD CONTRIBUTES TO SPECIES DIVERSITY AND PRESERVATION IN THE FACE OF CLIMATE CHANGE}

Highly complex changes to global ecosystems may be hard to grasp broadly but, at a site-specific level, the use of biophilic patterns or biome-specific references in design can help occupants develop a historical reference or narrative for what they're experiencing as part of an "occupant education" program. Climate change-related shifts in plant metabolism/behavior may include changes in leaf surface gas exchange rates, growth patterns, pollen counts, growing seasons, bioactive compounds (aerosols, root and leaf exudates-some of which may be irritants or ingredients in traditional medicines), location (changes in historical growing zone related to climate, soil composition and $\mathrm{pH}$ ), and changes in historical synergies/feedback loops with surrounding animals (both regional and migratory), plants, insects and microbes. Parks, greenways and water bodies provide critical habitat for a range of urban- or peri-urban species (either in transit to more hospitable circumstances or in place of habitat lost); buildings may provide de facto habitat or support valuable microcilmates. The health and productivity of our urban gardens and food forests depends in large part on the biodiversity we support in our communities, particularly among insects.

\section{AUTHOR CONTRIBUTIONS}

$\mathrm{JA}, \mathrm{JH}, \mathrm{VL}$, and $\mathrm{CRB}$ contributed to the conception, content, and revision of this paper. Colleagues from the International Living Future Institute's Biophilic Design Advisory Board (Julia Africa, Catherine Ryan Balagtas, Sonja Bochart, William Browning, Mary Davidge, David Gerson, Judith Heerwagen, Nicole Isle, Erin Jende, Vivian Loftness, Richard Piacintini, Malaysia Marshall, Tim McGee, and Amanda Sturgeon) participated in this process. Special thanks to Tim Beatley and the Biophilic Cities Network for their work at the urban scale.

Browning, W. D., Kallianpurkar, N. B., Ryan, C. O., and Labruto, L. (2012). The Economics of Biophilia: Why Designing With Nature Makes Financial Sense. New York, NY: Terrapin Bright Green llc, 40.

C40 Cities. Retrieved from: https://www.c40.org/other/the-future-we-don-twanthomepage (Accessed January 11, 2018).

Dadvand, P., Nieuwenhuijsen, M. J., Esnaola, M., Forns, J., and Basagaña, X. (2015). Green spaces and cognitive development in primary schoolchildren. Proc. Natl. Acad. Sci. U.S.A. 112, 7937-7942. doi: 10.1073/pnas.1503402112

Frumkin, H., Bratman, G. N., Breslow, S. J., Cochran, B., Kahn, P. H., Lawler, J. J., et al. (2017). Nature contact and human health: a research agenda. Environ. Health. Perspect. 125:075001. doi: 10.1289/EHP1663

Fuller, R. A., Irvine, K. N., Devine-Wright, P., Warren, P. H., and Gaston, K. J. (2007). Psychological benefits of greenspace increase with biodiversity. Biol. Lett. 3, 390-394. doi: 10.1098/rsbl.2007.0149

Grahn, P., and Stigsdotter, U. K. (2010). The relation between perceived sensory dimensions of urban green space and stress restoration. Landsc. Urban Plan. 94, 264-275. doi: 10.1016/j.landurbplan.2009.10.012

Hanna, E., and Tait, P.W (2015). Limitations to thermoregulation and acclimatization challenge human adaptation to global warming. Int. J. Environ. Res. Public Health 12, 8034-8074. doi: 10.3390/ijerph120708034 
Hoelscher, M. T., Nehls, T., Jänicke, B., and Wessolek, G. (2016). Quantifying cooling effects of facade greening: shading, transpiration and insulation. Energy Build. 114, 283-290. doi: 10.1016/j.enbuild.2015.06.047

Kellert, S. (2015). What Is and Is Not Biophilic Design. Metropolis Magazine. Available online at: https://www.metropolismag.com/architecture/what-isand-is-not-biophilic-design/ (Accessed Janary 12, 2019).

Kellert, S., Heerwagen, J., and Mador, M. (2008). Biophilic Design: The Theory, Science and Practice of Bringing Buildings to Life. New Jersey: John Wiley and Sons, Inc. Hoboken.

Klinenberg, E. (2018). Palaces for the People: How Social Infrastructure Can Help Fight Inequality, Polarization, and the Decline of Civic Life. New York, NY: Crown.

Kovats, R. S., and Hajat, S. (2008). Heat stress and public health: a critical review. Ann Rev Public Health 29, 41-45. doi: 10.1146/annurev.publhealth.29.020907.090843

Laurent, J. G. C., Williams, A., Oulhote, Y., Zanobetti, A., Allen, J. G., and Spengler, J. D. (2018). Reduced cognitive function during a heat wave among residents of non-air-conditioned buildings: an observational study of young adults in the summer of 2016. PLoS Med. 15:e1002605. doi: 10.1371/journal.pmed.1002605

Li, M., Gu, S., Bi, P., Yang, J., and Liu, Q. (2015). Heat waves and morbidity: Current knowledge and further direction-A comprehensive literature review. Int. J. Environ. Res. Public Health 12, 5256-5283. doi: 10.3390/ijerph1205 05256

Miller, M. (2018). Here's How Much Cities Contribute to the World's Carbon Footprint. Scientific American. Available online at: https://www. scientificamerican.com/article/heres-how-much-cities-contribute-to-theworlds-carbon-footprint (Accessed November 1, 2018).

National Academies of Sciences, Engineering, and Medicine (2017). Microbiomes of the Built Environment: A Research Agenda for Indoor Microbiology, Human Health, and Buildings. Washington, DC: The National Academies Press. doi: $10.17226 / 23647$

Quintero, I., and Weins, J.J (2013). Rates of projected climate change dramatically exceed past rates of climatic niche evolution among vertebrate species. Ecol. Lett. 16, 1095-1103. doi: 10.1111/ele.12144
Ryan, C. O., and Browning, W. D. (2018). "Biophilic design," Encyclopedia of Sustainability Science and Technology, ed R. Meyers (New York, NY: Springer).

Ryan, C. O., Browning, W. D., Clancy, J. O., Andrews, S. L., and Kallianpurkar, N. B. (2014). Biophilic design patterns: emerging nature-based parameters for health and well-being in the built environment. Archnet Int. J. Arch. Res. 8, 62-76. doi: 10.26687/archnet-ijar.v8i2.436

Sheweka, S. M., and Mohamed, N. M. (2012). Green facades as a new sustainable approach towards climate change. Energy Proc. 18, 507-520. doi: 10.1016/j.egypro.2012.05.062

Special Report on Global Warming of $1.5^{\circ} \mathrm{C}$ (2018). Incheon, Republic of Korea: Intergovernmental Panel on Climate Change (IPCC). Avaialble online at: https:// www.ipcc.ch/sr15/chapter/summary-for-policy-makers/ (Accessed January 7, 2019).

Watts, N., Adger, W. N., Agnolucci, P., Blackstock, J., Byass, P., Cai, W., et al. (2015). Health and climate change: policy responses to protect public health. Lancet 386, 1861-1914. doi: 10.1016/S0140-6736(15)60854-6

Williams, F. (2017). The Nature Fix: Why Nature Makes Us Happier, Healthier, and More Creative. New York, NY: WW Norton and Company.

Conflict of Interest Statement: JA is an independent Biophilic Design Consultant, formerly with the Harvard T. H. Chan School of Public Health. CRB is employed by Terrapin Bright Green LLC.

The remaining authors declare that the research was conducted in the absence of any commercial or financial relationships that could be construed as a potential conflict of interest.

Copyright (C) 2019 Africa, Heerwagen, Loftness and Ryan Balagtas. This is an openaccess article distributed under the terms of the Creative Commons Attribution License (CC BY). The use, distribution or reproduction in other forums is permitted, provided the original author(s) and the copyright owner(s) are credited and that the original publication in this journal is cited, in accordance with accepted academic practice. No use, distribution or reproduction is permitted which does not comply with these terms. 